\title{
Antimicrobial Susceptibility Pattern of Enteric Bacteria from Fresh cow milk and handlers in Zaria Metropolis, Kaduna State Nigeria
}

\section{Bilikis Abimbola Olunrebi*1, Josiah Ademola Onaolapo', Rebecca Olajumoke Bolaji', Sadiku Otaru²}

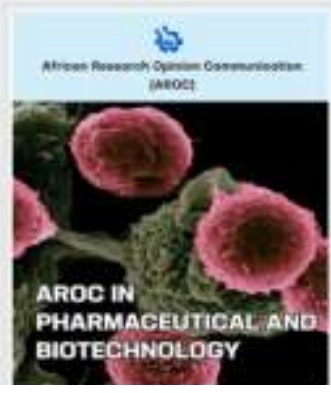

${ }^{1}$ Department of Pharmaceutical Microbiology, Ahmadu Bello University, Zaira, Kaduna State, Nigeria.

${ }^{2}$ National Animal Production and Research Institute (NAPRI), Zaira, Kaduna State, Nigeria.

*Corresponding author

Bilikis Abimbola Olunrebi

Email: bimm26@gmail.com

Mobile: +2347032827225

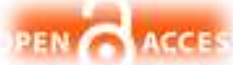

A bacteriological examination of raw cow milk for the isolation of enteric based bacteria was conducted on milking cows and their handlers from selected farms in four Local Governments in Zaria, Kaduna State. The aim of the study was to check the quality of the raw cow's milk and also verify the rate of contaminations of the raw cow's milk from external sources which are regarded as environmental pathogens during and after milking processes. A total of 105 samples; 42 raw milks from lactating cows, 42 swabs from cow teat, 16 swabs from herd handlers and 5 samples from water used in the cleaning process were obtained. The raw milk samples were screened using a Methylene dye reagent to check its microbial load before analysis began, the total bacteria count (TBC) and total coliform count (TCC) were analyzed using the standard cultural methods. The isolates were identified using the standard biochemical procedure and Microgen ${ }^{\mathrm{TM}}$ System (GN-ID A+B Kit). Results revealed that one hundred and two (102) bacteria consisting of Seventy-six (76) Polymicrobial and twenty-six (26) single cultures were recovered as positive culture while three (3) had no growth. The mean TBC and TCC of raw milk observed in this study were $2.56 \pm 0.40 \times 10^{4} \mathrm{cfu} / \mathrm{ml}$ and $1.06 \pm 0.16 \times 10^{4} \mathrm{cfu} / \mathrm{ml}$ respectively. Acinetobacter iwoffi and other members of Enterobacteriaceae isolates were resistant to tetracycline $(68.75 \%)$, erythromycin $(71.74 \%)$ and metronidazole (100\%), while high susceptibility was observed to gentamicin $(94.34 \%)$ and chloramphenicol $(80.85 \%)$. High bacterial contaminations including Multidrug-resistant bacteria were observed in this study, contaminations were majorly from improper pre and post dipping processes and the use of non-portable water.

Keywords: Bacteriological; Milking; Environmental pathogens; Hygiene and Isolation

Received: 12 October 2021, Revised: 05 November 2021, Published: 15 November 2021

Citation: Olunrebi, B.A., Onaolapo, J.A., Bolaji, R.O., and Otaru, S. (2021). Antimicrobial Susceptibility Pattern of Enteric Bacteria from Fresh cow milk and handlers in Zaria Metropolis, Kaduna State Nigeria. AROC in Pharmaceutical and Biotechnology, 1(2);35-42, https://doi.org/10.53858/arocpb01023542

\subsection{Introduction}

Milk is an aqueous colloidal suspension of protein, fats, carbohydrates and it contains numerous vitamins and minerals [1]. Raw milk is milk from any animal that has not been pasteurized or homogenized [2]. Raw milk essentially comes from a sterile environment within the animal, the risk of contamination begins within the udder, skin, feces, milking equipment, handling and storage $[3,4]$. Improper cleaning and sanitizing of the cow's udder is one of the major sources of high-level bacteria count in raw milk. In a study conducted in Santa Catarina, it was reported that the udder cleaning process was performed incorrectly, reinforcing the need for offering continuous training focused on showing dairy farmer how important is to sanitize the udders of the cows in order to have raw milk with low bacterial count [5]. The high amounts of bacteria found in refrigerated raw milk can be explained by the fact that in small farms there are several hygiene problems occurring during milking and raw milk storing processes $[6,7]$.

Coliform bacteria are normal inhabitants of soil, digestive tract and manure and they accumulate and multiply in contaminated bedding. Detection of coliforms plays an important role in the dairy industry because coliforms are frequently used as hygiene indicators and there are clear regulatory limits for the presence of coliforms in finished dairy products. For example, the US Pasteurized Milk Ordinance limits the number of coliforms in pasteurized grade " $\mathrm{A}$ " milk to $\leq 10 \mathrm{cfu} / \mathrm{mL}$ [8]. Coliform numbers of $1,000,000$ or more per gram of bedding increase the likelihood of an udder infection 
and clinical mastitis [9]. Mastitis caused by coliform is a cause of concern, the infection is usually confined to one or two quarter of the udder and the infection occurs very fast. Cows may appear healthy during a milking process and they could be sick during the next milking session. The raw milk from the sick cow usually appears watery or yellowish and contain flakes or clots. Escherichia coli, a major inhabitant of the intestines of all animals is mostly associated with coliform mastitis, when this enteric organism is allowed to spread unchecked because of unhygienic practices during milking process and dirty environmental factors, these could lead to serious problem and threat to the dairy chain [10].

The presence of coliform organisms in milk has been linked to a wide variety of human infections such as endocarditis, urinary and genital tract infections, meningitis and septicemia [11.] In this regard, similar studies related to ensuring raw milk safety need to be carried out in order to provide reliable information which can improve the quality of milk.

\subsection{Materials and Methods}

\subsection{Study design}

A cross-sectional study was carried out on raw cow milk supplied to the community for consumption and/or processing into other milk product. The study aimed at monitoring the rate of contamination of the raw milk samples, therefore, swab samples were taken from the cow teat and the handlers as well as some quantity of water used in the cleaning process on the farm. A total of 105 samples were collected for this study (Table 1). Selection of farms was based on; different management conditions, willingness of the farmers/pastoralists to participate in the study, and accessibility of the location, so that samples collected could be immediately transferred to the laboratory for further analysis.

\subsection{Sample collection}

Sampling was performed according to the International Dairy Federation guidelines [12]. Individual cows were properly restrained and the teats were washed and disinfected using a disposable paper towel immersed in a pre-dip iodine solution; in a concentration of one in ten milliliters $(1: 10)$ of iodine and water. This process of predipping was performed by the herd handlers and then a sterile swab stick was used to clean the udder. The first stream of milk was allowed to run off, thereafter, sample of raw milk was collected in sterile universal bottles and sealed air tight. Containers were marked with source of sample, the date and time of sampling and other relevant information. Also, sterile swab sticks were used to take samples from the handler and sample of the water used on the farm for cleaning were taken. After collection, the samples of raw milk were carried in ice box maintaining at a temperature of 4 $-5^{0} \mathrm{C}$ and brought to the laboratory, preserved in refrigerators within 1 hour until analysis begin.

Table 1: The Sampling data analysis

\begin{tabular}{|l|c|c|c|c|c|}
\hline Farm & Raw cow milk & Swab from teat & Swab from handler & Water & Total $(\%)$ \\
\hline Zango & 04 & 04 & 02 & 01 & $11(10.48)$ \\
\hline Jamaa Lima & 04 & 04 & 02 & 01 & $11(10.48)$ \\
\hline Kufenia & 03 & 03 & 02 & 01 & $09(8.57)$ \\
\hline NAPRI & 32 & 31 & 10 & 02 & $74(70.47)$ \\
\hline & 42 & 42 & 16 & 05 & $105(100)$ \\
\hline
\end{tabular}

\subsection{Media Preparation}

All glassware including petri dishes, test tubes and pipettes used in this analysis were sterilized using a hot oven at $180 \pm 5^{\circ} \mathrm{C}$ for at least 1 hour. Each bacteriological medium was prepared from commercially available powder according to the Manufacturer's instructions and sterilized by autoclaving at $121^{\circ} \mathrm{C}$ for 15 minutes.

\subsection{Isolation and Identification}

Tenfold serial dilutions of samples of raw cow milk were carried out in peptone water, then one hundred microliter $(0.1 \mathrm{ml})$ of $1: 10^{3}$ and $1: 10^{4}$ dilutions were plated out using surface plating technique on Nutrient Agar (NA) for total aerobic bacteria count (TBC) and MacConkey agar (MAC) for total coliform count (TCC) present in the raw milk sample. The inoculated plates were then inverted and incubated at $37^{\circ} \mathrm{C}$ for 24 hours. Thereafter, the plates were screened for the presence of discrete colonies and for each dilution, visible colonies that appeared were counted and the average were estimated as colony forming unit in per $\mathrm{ml}(\mathrm{cfu} / \mathrm{ml})$.

Individual pinkish colonies on MacConkey agar were picked and sub cultured onto freshly prepared MacConkey agar plate to confirm the cultural and morphological characteristics of the coliform isolate. Samples of teat swab, swab from handler and water used on farm were also cultured onto freshly prepared MacConkey medium, the cultured plates were incubated at $37^{\circ} \mathrm{C}$ for $24 \mathrm{~h}$. Representative colonies were stored in slant bottles containing 
freshly prepared nutrient agar and kept in the refrigerator $\left(4^{\circ} \mathrm{C}\right)$ until required for further work.

\subsection{Biochemical tests for Coliforms}

Conventional biochemical tests as reported by Cheesebrough [13], which include Catalase, Oxidase and Methyl red voges-proskauer (MRVP). They were done to preliminarily identify the bacteria isolates before using a commercial kit for Enterobacteriaceae (Medica-TecTM Microgen GN-ID $A+B$ Kit) to confirm the isolates to the specie level.

\subsection{Antimicrobial Sensitivity Testing}

Antimicrobial sensitivity was carried out on the coliform isolates using commercially prepared antimicrobials (Oxoid). Selected antibiotics used in this study are those commonly prescribed by doctors for food borne infections in Zaria metropolis. These include: Amoxicillin- clavulanic acid (AMC; 30 $\mu \mathrm{g})$, Ampicillin (AMP; $10 \mu \mathrm{g})$, Ceftazidime (CAZ; 10 $\mu \mathrm{g})$, Ciprofloxacin (CIP; $5 \mu \mathrm{g})$, Gentamicin (CN; $10 \mu \mathrm{g})$, Tetracycline (TET; $30 \mu \mathrm{g})$, Chloramphenicol $(\mathrm{CHL} ; 30 \mu \mathrm{g})$, Erythromycin (ERY; 15 $\mu \mathrm{g})$ and Metronidazole (MTZ; $10 \mu \mathrm{g}$ )

Discrete colony of isolates on nutrient agar plates were emulsified in $5 \mathrm{~mL}$ sterile physiological saline and turbidity adjusted to 0.5 McFarland standard (approximately a cell density $1.5 \times 10^{8} \mathrm{cfu} / \mathrm{mL}$ ) using the modified Kirby-Bauer method. The standardized suspension was inoculated on prepared Mueller-Hinton agar using sterile cotton swab stick to ensure an even distribution and confluent growth of the isolate. After inoculation, plates were allowed to dry before placing the antimicrobial disks aseptically using sterile forceps. The plates were incubated at $37^{\circ} \mathrm{C}$ for 24 hours after which the zone of inhibition was measured in millimeters $(\mathrm{mm})$ and compared against a reference standard and interpreted according to Clinical and Laboratory Standard Institute [14]

\subsection{Data Analysis}

The Statistical Package for Social Science (SPSS) version 20 was used to analyze the data. The result of sensitivity to tested antimicrobials were compiled in tabular forms.

\subsection{Result and Discussion}

The raw cow milk samples appeared fresh, creamy to whitish color with no curd formation observed. The $\mathrm{pH}$ readings of the sample milk were between 6.6-6.8 which were within the normal range of standard grade ' $A$ '. Sixty (60) bacteria species which are members of enterobacteriacea were isolated from this study with a prevalence rate of $35.5 \%$. Other bacteria species isolated include Micrococcus luteus, some group of Staphylococcus species. The mean total bacteria count (TBC) and total coliform count (TCC) observed in this study was $2.56 \pm 0.40 \times 10^{4} \mathrm{cfu} / \mathrm{mL}$ and $1.06 \pm 0.16 \times 10^{4}$ $\mathrm{cfu} / \mathrm{mL}$ respectively (Table 2 ).

Table 2: Mean Total Viable Count of Isolates from Fresh raw cow milk

\begin{tabular}{|l|l|l|}
\hline Farm & TBC $\left(\times 10^{4} \mathrm{cfu} / \mathrm{ml}\right)$ & TCC $\left(\times 10^{4} \mathrm{cfu} / \mathrm{ml}\right)$ \\
\hline Zango & $1.13 \pm 0.64$ & $0.58 \pm 0.70$ \\
\hline Sabo & $2.43 \pm 1.57$ & $0.98 \pm 0.83$ \\
\hline Kufenia & $0.8 \pm 0.79$ & $0.87 \pm 0.49$ \\
\hline NAPRI & $2.93 \pm 2.88$ & $1.16 \pm 1.1$ \\
\hline Overall Mean & $2.56 \pm 0.40$ & $1.06 \pm 0.16$ \\
\hline \multicolumn{2}{r}{ Key: } & TBC: Total Bacteria count, TCC; Total Coliform count \\
\hline
\end{tabular}

The prevalence observed in this study is relatively high when compared with report of a prevalence of $10.3 \%$ in Kaduna Nigeria [15], but considerably lower when compared with $52 \%$ reports in Sokoto Nigeria, and $61.1 \%$ in Ethiopia [16, 17]. The TBC and TCC observed in this study are relatively high when compared to the standard limits given by Food and Drug Association (FDA) pasteurized milk ordinance for grade A use [8] of $<10-10^{5} \mathrm{cfu} / \mathrm{mL}$ for total viable bacteria count and $\leq 10 \mathrm{cfu} / \mathrm{mL}$ for coliform count respectively. The result obtained in this study is however lower when compared with report of TBC and TEC of $0.2-4.2 \times 10^{6} \mathrm{CFU} / \mathrm{mL}$ and $0.8-2.6 \times 10^{6} \mathrm{CFU} / \mathrm{mL}$ respectively in Ogbomosho Nigeria [18].

\subsection{Bacteria Isolates from Farm}

Raw milk sampled from Zango and Jamaa lima farms have higher numbers of Staphylococci species (Table 3). Proteus vulgaris were the most recovered isolates from milk sampled from Kufenia farm and was also recovered from cow teat and handler swabs (Table 3 ). Raw milk sampled from NAPRI has higher numbers of occurrence of Acinetobacter iwoffi among the Enteriobactericea isolates and higher numbers of occurrence of Staphylococci species among the Gram-positive isolates (Table 3). $A$. iwoffi was also recovered from cow teat and handler swabs (Table 3 ). 
Table 3: Bacteria Isolation Pattern from Farm

\begin{tabular}{|c|c|c|c|c|c|c|}
\hline \multirow[t]{2}{*}{ Farm } & \multirow[t]{2}{*}{ Organism } & \multicolumn{4}{|c|}{ Source } & \multirow[t]{2}{*}{ Total $(\%)$} \\
\hline & & Milk & Teat & Handler & Water & \\
\hline \multirow[t]{5}{*}{ Zango } & Acinetobacter iwoffi & - & 01 & - & 01 & $02(40)$ \\
\hline & Klebsiella pneumoniae & - & - & 01 & - & $01(20)$ \\
\hline & Pasteurella multocida & 01 & - & - & - & $01(20)$ \\
\hline & Providencia stuartii & - & 01 & - & - & $01(20)$ \\
\hline & TOTAL & 01 & 02 & 01 & 01 & $05(100)$ \\
\hline \multirow{6}{*}{ Sabo } & Citrobacter youngae & - & - & - & 01 & $01(16.7)$ \\
\hline & Escherichia coli & - & - & 01 & - & $01(16.7)$ \\
\hline & Flavobacterium odoratum & - & 01 & - & - & $01(16.7)$ \\
\hline & Klebsiella oxytoca & - & 01 & - & - & $01(16.7)$ \\
\hline & Pseudomonas aeruginosa & 01 & - & 01 & - & $02(33.3)$ \\
\hline & TOTAL & 01 & 02 & 02 & 01 & $06(100.1)$ \\
\hline \multicolumn{7}{|l|}{ Kufenia } \\
\hline & Acinetobacter iwoffi & - & 01 & - & - & $01(10)$ \\
\hline & Aeromonas caviae & 01 & - & - & - & $01(10)$ \\
\hline & Citrobacter freundi & 01 & - & - & - & $01(10)$ \\
\hline & Escherichia coli & - & - & - & 01 & $01(10)$ \\
\hline & Proteus vulgaris & 02 & 02 & 01 & - & $05(50)$ \\
\hline & Yersinia enterocolitica & - & - & 01 & - & $01(10)$ \\
\hline & TOTAL & 04 & 03 & 02 & 01 & $10(100)$ \\
\hline \multicolumn{7}{|l|}{ Giwa } \\
\hline & Acinetobacter iwoffi & 08 & 03 & 01 & - & $12(30.8)$ \\
\hline & Aeromonas hydrophila & 03 & - & - & - & $03(7.7)$ \\
\hline & Burkholderia pseudomallei & 01 & - & - & - & $01(2.6)$ \\
\hline & Escherichia coli & 01 & - & - & - & $01(2.6)$ \\
\hline & Hafnia alvei & 01 & 01 & - & - & $02(5.1)$ \\
\hline & Moraxella specie & 04 & 01 & 01 & 01 & $07(17.9)$ \\
\hline & Pantoea agglomerans & 02 & - & 01 & - & $03(7.7)$ \\
\hline & Plesiomonas shigelloides & 01 & - & - & - & $01(2.6)$ \\
\hline & Proteus mirabilis & - & - & 01 & - & $01(2.6)$ \\
\hline & Proteus vulgaris & & - & 01 & 01 & $02(5.1)$ \\
\hline & Providencia stuartii & & - & 01 & - & $01(2.6)$ \\
\hline & Pseudomonas aeruginosa & 02 & - & - & - & $02(5.1)$ \\
\hline & S. choleraesus & & & - & - & $01(2.6)$ \\
\hline & Vibrio parahaemolyticus & 01 & - & - & - & $01(2.6)$ \\
\hline & Weeksela zoohelcum & & - & 01 & - & $01(2.6)$ \\
\hline & TOTAL & 24 & 08 & 06 & 01 & $39(100.2)$ \\
\hline
\end{tabular}

Isolation of E. coli, Klebsiella specie, Proteus specie and Enterobacter specie from fresh cow milk in Sokoto Nigeria [16], this report is in close agreement with the findings from this study. Also, in a cross-sectional study carried out in Gondar town, Ethiopia identified 54 different bacterial species, and they include E. coli, Pseudomonas aeruginosa and Klebsiella pneumoniae as the most commonly identified gram-negative staining bacterial pathogens which is similar to the findings from this study [17].

In addition, majority of coliform isolates from a study conducted using the raw milk consumed in Khartoum, Sudan were E. coli, Enterobacter specie, Klebsiella specie, Serratia specie and Citrobacter [19], which closely agree to the findings from this study.

\subsection{Antimicrobial Resistance observed among the Enterobacteriaceae}

The antimicrobial resistance pattern observed among the identified Enterobacteriaceae species were Amoxicillin- Clauvulanic (67.31\%), Tetracycline (68.75\%), Erythromycin (71.74\%), Ceftazidime $(88.68 \%)$ and Metronidazole (96\%) which is in close agreement to antimicrobial resistance of tetracycline and erythromycin reported in Kaduna, Nigeria [15], and resistance to erythromycin $(85.71 \%)$ reported in Zaria, Nigeria [20]. Susceptibility was highly shown to Gentamicin (94.34\%), Chloramphenicol (80.85\%), and Ciprofloxacin (77.08\%) among the identified Enterobacteriacea in this study (Table 4), which is similar to Gentamicin and Ciprofloxacin (100\%), Chloramphenicol (93\%) reported in Zaria, Nigeria 
[20] and also similar to reports of susceptibility to both gentamicin and Ciprofloxacin in all the tested isolates of coliform from raw milk in Ogbomosho, Nigeria [18].
Table 5 shows the pattern of resistance exhibited in the present study, this may be due to prolonged and indiscriminate usage and prescription of related antibiotics which often leads to possible resistance development in animals $[21,22]$.

Table 4: In-vitro Sensitivity testing of bacterial isolates to nine antimicrobials.

\begin{tabular}{|l|l|l|l|l|l|}
\hline Drug Class & Antimicrobials & content (ug) & N & Resistance (\%) & \multicolumn{1}{l|}{ Susceptible(\%) } \\
\hline Cephalosporins & Ceftazidime & 10 & 53 & $47(88.68)$ & $6(11.32)$ \\
\hline Tetracycline & Tetracycline & 30 & 48 & $33(68.75)$ & $15(31.25)$ \\
\hline Fluoroquinolones & Ci[profloxacin & 5 & 48 & $11(22.92)$ & $37(77.08)$ \\
\hline Penicillin & Amoxi-Clavulanic & 30 & 52 & $35(67.31)$ & $17(32.69)$ \\
\hline Penicillin & Ampicillin & 10 & 36 & $19(52.78)$ & $17(47.22)$ \\
\hline Aminoglycosides & Gentamicin & 10 & 53 & $3(5.66)$ & $50(94.34)$ \\
\hline Macrolides & Erythromycin & 15 & 46 & $33(71.74)$ & $13(28.26)$ \\
\hline Phenicols & Chloramphenicol & 30 & 47 & $9(19.15)$ & $38(80.85)$ \\
\hline Nitro imidazole & Metronidazole & 10 & 52 & $52(100)$ & - \\
\hline
\end{tabular}

key: $\mathrm{N}$ indicates number of tested Isolates; \% Resistance indicates calculated resistant isolates; \% Susceptibility indicates calculated susceptible isolates

Table 5: Antibiotic Resistance Pattern of Enterobacteriaceae isolates

\begin{tabular}{|c|c|c|c|c|c|c|c|c|c|c|}
\hline \multirow[t]{2}{*}{$\mathrm{S} / \mathrm{N}$} & \multirow[t]{2}{*}{ Bacteria isolates } & \multicolumn{9}{|c|}{ Antibiotic Resistance (\%) } \\
\hline & & CAZ & TET & CIP & AMP & $\mathrm{CN}$ & ERY & AMC & $\mathrm{CHL}$ & MTZ \\
\hline 1. & Acinetobacter iwoffii $(n=14)$ & 85.7 & 35.7 & 7.1 & 42.9 & 7.1 & 42.9 & 78.6 & 14.3 & 100 \\
\hline 2. & Aeromonas hydrophila $(n=03)$ & 100 & 33.3 & 0 & 66.7 & 0 & 100 & 100 & 33.3 & 100 \\
\hline 3. & Burkholderia pseudomallei $(\mathrm{n}=01)$ & 0 & 100 & 100 & - & 0 & 100 & 100 & 0 & 100 \\
\hline 4. & Citrobacter freundi $(n=01)$ & 100 & 0 & 0 & 0 & 0 & 100 & 0 & 0 & 100 \\
\hline 5. & Citrobacter youngae $(n=01)$ & 100 & 100 & 100 & 100 & 100 & 100 & 100 & 0 & 100 \\
\hline 6. & Escherichia coli $(n=02)$ & 100 & 0 & 0 & 50 & 0 & 0 & 50 & 0 & 100 \\
\hline 7. & Hafnia alvei $(n=02)$ & 0 & 50 & 50 & 0 & 0 & 50 & 50 & 0 & 50 \\
\hline 8. & Klebsiella oxytoca (n & 100 & 100 & 0 & 100 & 0 & 100 & 100 & 0 & 100 \\
\hline 9. & Klebsiella pneumoniae $(\mathrm{n}=01)$ & 100 & 0 & 0 & 100 & 0 & 100 & 100 & 0 & 100 \\
\hline 10. & Moraxella specie $(n=06)$ & 100 & 100 & 0 & 50 & 16.7 & 33.3 & 50 & 16.7 & 100 \\
\hline 11. & Pantoea agglomerans $(n=03)$ & 33.3 & 66.7 & 0 & 0 & 0 & 66.7 & 33.3 & 0 & 66.7 \\
\hline 12. & Pasteurella multocida $(n=01)$ & 100 & 100 & 0 & 100 & 0 & 100 & 100 & 100 & 100 \\
\hline 13. & Plesiomonas shigelloides $(n=01)$ & 100 & 0 & 0 & 100 & 0 & 100 & 100 & 100 & 100 \\
\hline 14. & Proteus vulgaris $(n=07)$ & 100 & 71.4 & 57.1 & 42.9 & 0 & 85.7 & 42.9 & 0 & 100 \\
\hline 15. & Proteus mirabilis $(\mathrm{n}=01)$ & 100 & 100 & 0 & 100 & 0 & 100 & 0 & 0 & 100 \\
\hline 16. & Providencia stuarti $(\mathrm{n}=02)$ & 100 & 50 & 50 & 50 & 0 & 50 & 0 & 0 & 100 \\
\hline 17. & Pseudomonas aeruginosa $(n=03)$ & 100 & 100 & 33.3 & 66.7 & 0 & 100 & 100 & 66.7 & 100 \\
\hline 18. & S. choleraesus & 100 & 100 & 0 & 100 & 0 & 0 & 100 & 100 & 100 \\
\hline 19. & Vibrio parahaemolyticus & 100 & 100 & 0 & 100 & 0 & 0 & 100 & 0 & 100 \\
\hline 20. & Weeksela zoohelcum & 100 & 0 & 0 & 0 & 0 & 0 & 0 & 0 & 100 \\
\hline 21. & Yersinia enterolitica & 100 & 100 & 100 & 100 & & 100 & 100 & 0 & 100 \\
\hline
\end{tabular}

$\mathrm{CAZ}=$ Ceftazidime, $\mathrm{AMP}=$ Ampicillin, $\mathrm{AMC}=$ Amoxicillin Clavulanic acid, $\mathrm{TET}=$ Tetracycline, $\mathrm{CN}=$ Gentamicin, $\mathrm{CHL}=$ Chloramphenicol, CIP = Ciprofloxacin, ERY = Erythromycin, MTZ= Metronidazole

Overall, $53.8 \%$ of the isolates were multidrug resistant. There was no significant association between sample source and multi-resistance phenotype, however, isolates from teat swabs were more likely to be non-multidrug resistant $(p=$ 0.555). There was no significant association between sampling location and multi-resistance phenotype, however, isolates from Zango farm were more likely to be non-multidrug resistant compared to strains from Sabo farm, most of which were extensively drug resistant $(p=0.145)$.
Acinetobacter iwoffii isolates were multidrug resistant, while Pseudomonas aeruginosa were extensively drug resistant (Table 6). In this study, the percentage of multiple antibiotic resistance index (MARI) of greater than or equal to 0.3 was observed to be; $92 \%$ for Enterobacteriaceae (Table 7). 
Table 6: Multidrug Resistance Classification of Enterobacteriaceae isolates

\begin{tabular}{|c|c|c|c|c|c|}
\hline \multirow[t]{2}{*}{$\mathbf{S} / \mathbf{N}$} & \multirow[t]{2}{*}{ Bacteria isolates } & \multicolumn{4}{|c|}{$(\%)$} \\
\hline & & PDR & XDR & MDR & nMDR \\
\hline 1. & Acinetobacter iwoffii $(n=14)$ & 0 & 21.4 & 71.4 & 7.1 \\
\hline 2. & Aeromonas hydrophila $(\mathrm{n}=03)$ & 0 & 66.7 & 33.3 & 0 \\
\hline 3. & Burkholderia pseudomallei $(\mathrm{n}=01)$ & 0 & 0 & 100 & 0 \\
\hline 4. & Citrobacter freundi $(\mathrm{n}=01)$ & 0 & 0 & 100 & 0 \\
\hline 5. & Citrobacter youngae $(n=01)$ & 0 & 100 & 0 & 0 \\
\hline 6. & Escherichia coli $(n=02)$ & 0 & 0 & 50 & 50 \\
\hline 7. & Hafnia alvei $(\mathrm{n}=02)$ & 0 & 0 & 50 & 50 \\
\hline 8. & Klebsiella oxytoca $(n=01)$ & 0 & 100 & 0 & 0 \\
\hline 9. & Klebsiella pneumoniae $(\mathrm{n}=01)$ & 0 & 0 & 100 & 0 \\
\hline 10. & Moraxella specie $(n=06)$ & 0 & 33.3 & 66.7 & 0 \\
\hline 11. & Pantoea agglomerans $(n=03)$ & 0 & 0 & 66.7 & 33.3 \\
\hline 12. & Pasteurella multocida $(\mathrm{n}=01)$ & 0 & 100 & 0 & 0 \\
\hline 13. & Plesiomonas shigelloides $(n=01)$ & 0 & 100 & 0 & 0 \\
\hline 14. & Proteus vulgaris $(\mathrm{n}=07)$ & 0 & 42.9 & 57.1 & 0 \\
\hline 15. & Proteus mirabilis $(\mathrm{n}=01)$ & 0 & 0 & 100 & 0 \\
\hline 16. & Providencia stuarti $(\mathrm{n}=02)$ & 0 & 50 & 0 & 50 \\
\hline 17. & Pseudomonas aeruginosa $(n=03)$ & 0 & 100 & 0 & 0 \\
\hline 18. & S. choleraesus & 0 & 100 & 0 & 0 \\
\hline 19. & Vibrio parahaemolyticus & 0 & 0 & 100 & 0 \\
\hline 20. & Weeksela zoohelcum & 0 & 0 & 0 & 100 \\
\hline 21. & Yersinia enterolitica & 0 & 100 & 0 & 0 \\
\hline
\end{tabular}

Table 7: Multiple Antibiotic Resistance Index (MARI) of Enterobacteriaceae isolates

\begin{tabular}{|c|c|c|c|}
\hline MARI & Distribution & Percentage (\%) \\
\hline 0.2 & 04 & 8 \\
\hline 0.3 & 08 & 16 & \\
\hline 0.4 & 05 & 10 & \\
\hline 0.5 & 04 & 8 \\
\hline 0.6 & 11 & 22 & \\
\hline 0.7 & 07 & 14 \\
\hline 0.8 & 08 & 16 \\
\hline 0.9 & 03 & 6 \\
\hline & 50 & & \\
\hline & & \\
\hline
\end{tabular}

There are several improper sanitary checks done on the farm which could have resulted in contamination of the raw milk. These include; Unavailability of good portable water used on the farms; and improper udder preparations by inadequate washing and disinfecting with detergent; and improper preand post- dipping solutions; and improper periodic handwashing by the handlers, these are reasonable means of introducing contaminations directly into the raw milk. The report in this study revealed on the average low level of education and awareness among small scale dairy farm handlers on need to maintain adequate hygiene level during milking practices. Therefore, regulatory bodies are summoned to ensure periodic assessment and reinforcing measures to educate and monitor the dairy value chain practices in areas of concern. Importantly, the populace needs to be readily informed and/ or reminded about the risk and dangers of consuming raw milk irrespective of their cultural beliefs, as well as educated on the need to pasteurize the raw milk before consumption.

\subsection{Conclusion}

Majority of the farm owners and handlers do not observe pre-dipping and post-dipping cleaning processes or it is performed incorrectly, which could have resulted in high bacterial contaminations including Multidrug resistant bacteria observed in this study. Additionally, the analysis on the water used on four farms visited in this study showed the presence of high bacterial load, especially members of the Enterobacteriaceae, all these could be the leading source of contamination of the raw cow milk.

Authors Contributions: The work was conducted and reviewed in collaboration of all authors. All 
authors have read and agreed to the published version of the Manuscript.

Funding: This work received no external funding.

Institutional Consent Statement: Not Applicable

Acknowledgments: Not Applicable

Conflict of Interest: The Authors declare that no conflict of Interest exists.

Ethical Consideration: Ahmadu Bello University ABU Committee for Use of Animal Subjects for Research (ABUCUHSR) and Ethical Committee of National Animal Production Research Institute (NAPRI) Shika, Zaria.

\section{REFRENCES}

1 Ogbolu D.O., Terry-Alli A.O., Oluremi A.S. and Olanrewaju A.A. (2014). Microbial contamination of locally produced cheese and determination of their antimicrobial potential in Nigeria. African Journal of Clinical and Experimental Microbiology 15(2): 76-83.

2 Centers for Disease Control and Prevention (2012).ttps://www.cdc.gov/features/rawmil k/index.html

3 John A. Lucky, (2015). Raw Milk Consumption; Risks and Benefits. Nutrition Today. 50 (4):189-193.

4 Cancino-Padilla N., Fellenberg M A.,Franco W., Ibanez R A. and Vargas-Bello-Perz E. (2017). Foodborne bacteria in dairy Products: Detection by molecular techniques.Ciencia Investigation Agraria: 8:215-229

5 Maldaner, N., Diane S., Debora O. and Eliandra M. (2012). Evaluation of Microbiological Quality of Raw Milk Produced at Two Properties in the Far West of Santa Catarina, Brasil. Food and Public Health, 2, 79-84

6 Mhone, T. A.; Matope, G. and Saidi, P. T. (2011). Aerobic bacterial, coliform, Escherichia coli and Staphylococcus aureus counts of raw and processed milk from selected smallholder dairy farms of Zimbabwe. International Journal of Food Microbiology, 151, 223-228.
Suranindyah, Y., Wahyuni E., Bintara S., and Purbaya G. (2015). The effect of improving sanitation prior to milking on milk quality of dairy cow in farmer group. Procedia Food Science, 3, 150-155.

FDA. 2011. Standards for grade "A" milk and milk products. Pages 27-30 in Grade "A" Pasteurized Milk Ordinance. Standards for grade "A" milk and milk products. US Department of Health and Human Services, Public Health Service, Washington, DC.

9 Podder MP, Rogers L, Daley PK, Keefe GP, Whitney HG, Tahlan K (2014). Klebsiella species Associated with Bovine Mastitis in Newfoundland. PLOS ONE 9(9):106518.

Raghvendra Kumar Mishra, Rajesh Singh Tomar and Monika Gupta (2017). International Journal Pharmaceutical Biological Science; 8(3):(B) 100-104.

11 Centers for Disease Control and Prevention (2015).

https://www.cdc.gov/foodsafety/rawmilk/ra wmilk-index.html

12 International Dairy Federation (IDF. 1995). Milk and milk product- guidance on sampling, IDF Standard 50C. Brussels, Belgium: International Dairy Federation.

13 Cheesbrough, M. (2006). District Laboratory Practice in Tropical Countries. Part 2. Low Price Edition. Cambridge University Press, London.

14 Clinical and Laboratory Standard Institute (CLSI) (2018). Performance Standards for antimicrobial susceptibility testing. 26th edition. CLSI document M100-S26. Wayne, PA

15 Mbuk E. U., Kwaga J.K.P., Bale J.O.O., Boro L.A. and Umoh J.U., (2016). Coliform organisms associated with milk of cows with mastitis and their sensitivity to commonly available antimicrobials in Kaduna. Nigeria. Journal of Veterinary Medcine and Animal Health. 8(12): 228-236.

16 Junaidu A.U., Salihu M.D., Tambuwala F.M., Magaji A.A. and Jaafaru S. (2011). Prevalence of mastitis in lactating cows in some selected commercial dairy farms in Sokoto Metropilis. Pelagia Advance of Applied Science Research 2(2: 290-294. 
17 Garedew L, Berhanu A, Mengesha D, Tsegay $G$ (2012). Identification of gram-negative bacteria from critical control points of raw and pasteurized cow milk consumed at Gondar town and its suburbs, Ethiopia. BMC Public Health pp.12-950.

18 Oladipo I.C., Tona G.O, Akinlabi E.E and Bosede O.E (2016). Bacteriological quality of raw cow's milk from different dairy farms in Ogbomosho Nigeria. International Journal of Advanced Research in Biological sciences; 3(8): 1-6.

19 Salman AMA, Hamad IM (2011). Enumeration and identification of coliform bacteria from raw milk in Khartoum State, Sudan. Journal of Cell Animal Biology 5(7):121-128.
20 Tamba Z., Bello M. and Raji M.A. (2016). Occurrence and Antibiogram of Salmonella specie in Raw and Fermented Milk in Zaria and Environs. Bangledash Journal of Veterinary Medicine. 14(1): 103-107.

21 Kwaga JKP (2012). Veterinary intervention on the global challenge of antimicrobial resistance. Paper presented at the World Veterinary Day Celebration, 28th April, 2012. NVMA, Kaduna.

22 Sharma M, Dogra BB, Misra R, Gandham N, Sardar M, Jadhav S (2014). Multidrug resistant Pantoea agglomerans in a patient with septic arthritis-a rare report from India. International Journal of Microbiology Research. 4:263-265.
Submit your article to AROC JOURNALS -AROC in Pharmaceutical and Biotechnology -AROC in Agriculture

-AROC in Bioinformatics

-AROC in Food and Nutrition

-AROC in Natural Product Research

-BIOMED Natural and Applied Science

Visit: https://arocjournal.com/

Copyright (c) 2021 Olunrobi et al. This is an open access article distributed under the terms and conditions of the Creative Commons Attribution License (https://creativecommons.org/licenses/by/4.0/) 